Athens Journal of Humanities \& Arts - Volume 9, Issue 3, July 2022 - Pages 261-274

\title{
Some Remarks on the Five Criteria of Democracy
}

\author{
By Panagiotis Petratos*
}

\begin{abstract}
In a recent article published in this journal, Gregory T. Papanikos presented and discussed the five criteria of democracy. This paper further discusses these criteria by providing some additional ancient sources in light of the modern application of democracy in various countries. It is shown that these five criteria had a diachronic effect in ancient Athens as is demonstrated by a number of ancient writers. I use excerpts from some ancient works to show that this was the case.
\end{abstract}

\section{Introduction}

This paper is inspired by reading the journal article authored by Gregory T. Papanikos. ${ }^{1}$ The five criteria for democracy in ancient Athens are isegoria, isonomy, isocracy, isoteleia and isopoliteia. ${ }^{2}$ In the research study by Papanikos, ${ }^{3}$ a review and a comparison is reported of the political system of the true democracy in ancient Athens compared with the modern democracy of the very few elected representatives. Modern democracy is quite dissimilar to the democracy of ancient Athens. ${ }^{4}$ Modern democracy is based on a political system of a few elected representatives who vote on behalf of the people on very important laws, public financial budgets, public projects' finances, and all other

"Professor, California State University Stanislaus, USA.

1. G. T. Papanikos, "“The Five Ancient Criteria of Democracy: The Apotheosis of Equality," Athens Journal of Humanities \& Arts 9, no. 2 (2022): 105-120.

2. B. Akrigg, "The Nature and Implications of Athens' Changed Social Structure and Economy," Debating the Athenian Cultural Revolution: Art, Literature, Philosophy, and Politics (2007): 430-380; M. Amit, “The Sailors of the Athenian Fleet," Athenaeum 40 (1962): 157-178; P. Vidal-Naquet, Economic and Social History of Ancient Greece: An Introduction (Berkeley: University of California Press, 1977); G. Anderson, The Athenian Experiment: Building an Imagined Political Community in Ancient Attica, 508-490 BC (University of Michigan Press, 2003).

3. Papanikos, "The Bright Future of Democracy is in Education," Athens Journal of Education 9, no. 2 (2022): 353-364.

4. Papanikos, The Use of European History: Lessons for the 21st Century History (Mimeo, 2005); Papanikos, "The Use of History as a Tool of Policy-Making," in 4th International Conference on History: From Ancient to Modern (Athens: National Archaeological Museum of Athens, 2006); Papanikos, "Taxing Wealth and Only Wealth in an Advanced Economy with an Oversized Informal Economy and Vast Tax Evasion: The Case of Greece," Vierteljahrshefte zur Wirtschaftsforschung 84, no. 3 (2015): 85-106; Papanikos, "Collective Decision-Making in Homer's Odyssey," Athens Journal of Mediterranean Studies 7, no. 1 (2021): 59-84. 
matters of social and public concern, such as energy security, etc. ${ }^{5}$ Voting on behalf of the people or voting in favor of the people's financial interests is not always followed by the very few elected representatives who often vote to protect and increase their own wealth and financial interests, or to protect and increase the oligarchy's wealth and financial interests. ${ }^{6}$

The democracy of ancient Athens is based on a political system whereby all citizens vote--with no representatives required-to protect and increase the people's own wealth and financial interests, not to protect and increase the oligarchy's wealth and financial interests, like the so-called very few elected representatives vote. ${ }^{7}$ Therefore, the true democracy of ancient Athens is based on a political system whereby all citizens participate in the decision-making process for all very important matters of social and public concern in order to protect and increase all people's wealth and financial interests. ${ }^{8}$

The political system of what can be called true democracy of ancient Athens evidently comes into direct opposition to the oligarchy's financial interests. ${ }^{9}$ This

5. M. M. Austin, "Economy and Society," in The Cambridge Ancient History: Volume IV: The Fourth Century (eds.) D. M. Lewis, J. Boardman, S. Hornblower, and M. Ostwald, second edition, 527-564 (Cambridge, 1994); E. Badian, "The Road to Prominence," in Demosthenes: Statesman and Orator (ed.) I. Worthington, 9-44 (London and New York, 2000); R. Balot, "Courage in the Democratic Polis," The Classical Quarterly 54, no. 2 (2004): 406-423; Balot, "The Dark Side of Democratic Courage," Social Research: An International Quarterly 71, no. 1 (2004): 73-106; Balot, Greek Political Thought (John Wiley \& Sons, 2008); Balot, Greed and Injustice in Classical Athens (Princeton University Press, 2020); Papanikos, "Energy Security, the European Energy Union and the Mediterranean Countries," Athens Journal of Mediterranean Studies 3, no. 4 (2017): 341-354.

6. G. Barjamovic, Civic Institutions and Self-Government in Southern Mesopotamia in the Mid-First Millennium BC (na, 2004); J. M. Barringer, The Hunt in Ancient Greece (JHU Press, 2001); K. Bassi, "The Semantics of Manliness in Ancient Greece," in Andreia, 25-58 (Brill, 2003).

7. J. G. Best, Thracian Peltasts and their Influence on Greek Warfare (Wolters-Noordhoff, 1969); D. Blackman, “Archaeology in Greece 1996-97," Archaeological Reports 43 (1996): 1125; D. D. Boedeker, and K. A. Raaflaub, Democracy, Empire, and the Arts in Fifth-Century Athens (Cambridge, Mass: Harvard University Press, 1998).

8. A. L. Boegehold, and A. C. Scafuro (Eds.), Athenian Identity and Civic Ideology (Baltimore, 1994; D. W. Bradeen, "The Athenian Casualty List of 464 BC," Hesperia: The Journal of the American School of Classical Studies at Athens 36, no. 3 (1967): 321-328; J. M. Bremer, "Aristophanes on his Own Poetry," in Aristophane (eds.) J. M. Bremer and E. W. Handley, 125-165 (Geneva, 1993).

9. R. Brock, "The Emergence of Democratic Ideology," Historia 40 (1991): 160-169; Brock, and S. Hodkinson, "Introduction: Alternatives to the Democratic Polis," in Alternatives to Athens: Varieties of Political Organization in Ancient Greece (eds.) R. Brock, and S. Hodkinson, 1-43 (Oxford, 2000); P. Brun, Eisphora - Syntaxis - Stratiotika: Recherches sur les Finances Militaires d'Athènes au IVe Siècle av. J.-C. (Besançon and Paris, 1983); J. M. 
is the reason that the oligarchy preferred to rule on its own, based on the oligarchic political system.

An even more restricted form of government is to protect and enrich the financial interests of not only the very few (also known as oligarchy), but of the one individual in power known as monarchy. Sometimes monarchy may be benevolent if the monarch, the individual who governs and rules all, is truly enlightened and makes all decisions to protect and increase the wealth and financial interests of all their subjects, citizens and all people, which yield the same results of true democracy in ancient Athens. ${ }^{10}$

Unfortunately, this is not often the case and the reality of a monarchy is that the one individual in power who governs and rules all is interested only in protecting and increasing their own wealth and financial interests. This is usually accomplished at the expense and the financial detriment of all people through widespread and heavy taxation. When the monarch enforces unbearable taxation to all citizens for example, then the monarchy is turned into a tyranny.

The tyrant in power can also enforce other unbearable laws. For example, the tyrant can impose significant financial costs upon the people and prepare to go war with a neighbor state simply to increase the tyrant's own wealth and financial gain. War is never won without any losses of human lives, and usually it is a significant number of human lives lost. Significant losses of human lives are the ultimate price for the people to pay in order to satisfy the tyrants' uppishness.

\section{Historical Review of Notable Political Systems}

Hellas, also known as Greece, is derived from the Latin name Graecia

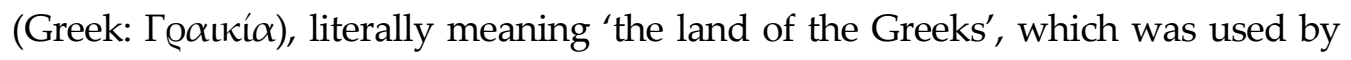
ancient Romans to denote the area of modern-day Greece. ${ }^{11}$

Bryant, "Military Technology and Socio-Cultural Change in the Ancient Greek City," Sociological Review 38 (1990): 484-516.

10. G. R. Bugh, The Horsemen of Athens (Princeton, 1988); P. Burian, "Myth into Muthos: The Shaping of Tragic Plot," in The Cambridge Companion to Greek Tragedy, 206, 1997; B. Campbell, "Paradigms Lost Classical Athenian Politics in Modern Myth," History of Political Thought 10, no. 2 (1989): 189-213; J. L. Cargill, The Second Athenian League: Empire or Free Alliance? (Berkeley \& Los Angeles, 1981); T. Carothers, "The Backlash Against Democracy Promotion," Foreign Affairs (2006): 55-68.

11. L. Carson, P. F. L. Carson, and B. Martin, Random Selection in Politics (Greenwood Publishing Group, 1999); G. L. Cawkwell, "The Defence of Olynthus," The Classical Quarterly 12, no. 1 (1962): 122-140; Cawkwell, "Demosthenes and the Stratiotic Fund," Mnemosyne 15 (Fasc. 4) (1962): 377-383; Cawkwell, "Eubulus," The Journal of Hellenic Studies 83 (1963): 47-67; Cawkwell, "Athenian Naval Power in the Fourth Century," The Classical Quarterly 34, no. 2 (1984): 334-345; Cawkwell, "Orthodoxy and Hopiltes," The Classical Quarterly 39, no. 2(1989): 375-389. 
History states that certain peoples' rising with military power ${ }^{12}$ at various periods of time, short or long, dominated the known world or at least a large part of the known world. ${ }^{13}$ From history we also know that certain people have claimed all the wealth of the known world, as full-fledged privilege, in their perception, violently or peacefully, proclaiming themselves the so-called leaders of humanity. For example, typical evidence of this phenomenon is the belief that the pharaohs, who were the monarchs of ancient Egypt, were not only the kings of the Egyptian people, but also the pharaohs were the sole representatives of the Gods and the singular individual mediators between the deities and the world of men.

Many eons later in the land of the pharaohs, Egypt was annexed by the Roman Empire. Romans in their time of rise and acme created the Roman Empire and conquered the greatest part of the known world. The spiritual and political formation of the Roman Empire, and in general the Romans' pedagogical upbringing, was such that they entered life with the understanding that their destiny was to conquer the world, as Nicolet rightly observes. ${ }^{14}$

The notable poet Vergil (Vergilius Maro, Aeneid) obviously wished to remind us of the arrogant ideology of Romans in his verse: "But thou, Roman, learn with sovereign sway To rule the nations.." ${ }^{15}$ However, this perception according to Montesquieu ${ }^{16}$ finally proved detrimental to their military power and contributed to the fall of the Roman Empire.

One of the principal reasons for the decline and fall of the Roman Empire was their lack of mental and spiritual excellence. Instead of spiritual excellence, Romans adopted their prevailing military power and violence as well as the common practice "divide and conquer".

12. Even nowadays, corruption and non-democratic political regimes may be related to military spending: Papanikos, "Military Spending, International Trade and Economic Growth in the Mediterranean Basin," Athens Journal of Mediterranean Studies 1, no. 2 (2015): 187-194.

13. P. Cartledge, "The Machismo of the Athenian Empire-Or the Reign of the Phaulus?" When Men Were Men: Masculinity, Power and Identity in Classical Antiquity (1998): 54-67; Cartledge, Spartan Reflections (Berkeley, 2001); Cartledge, The Effects of the Peloponnesian (Athenian) War on Athenian and Spartan Societies (McCann, 2001); K. A. Raaflaub, J. Ober, and R. W. Wallace. Origins of Democracy in Ancient Greece (Berkeley: University of California Press, 2007); M. I. Finley, Politics in the Ancient World (Cambridge University Press, 1983); N. R.E. Fisher, Recherches sur la Nature du Génos: Étude d'histoire Sociale Athénienne-Périodes Archaïque et Classique, 1979; E. C. Moignard, Berard et al. A City of Images: Iconography and Society in Ancient Greece (Princeton University Press, 2009).

14. C. Nicolet, Space, Geography, and Politics in the Early Roman Empire (University of Michigan Press, 1991).

14. Vergil, "Aeneid," in Book VI, 846-853 (Boston: Houghton Mifflin Co., 1910).

16. C. D. Montesquieu, “Considérations sur les Causes de la Grandeur des Romains et de leur Décadence (1734)," Montesquieu. Oeuvres Complètes. Paris: Gallimard (1949): 69-209. 
Romans were undermined and therefore overthrown by the advanced peoples whom the Romans had enslaved. As Horatio, the great Latin poet, referred to this phenomenon of peaceful overpower, wrote that, "Captive Greece held captive her uncivilized conqueror and brought the arts to the rustic Latin lands!"17 precisely of the Greek civilization and of the Greek spirit.

Many eons later another example of this phenomenon is the pursuit of world dominance by the German military during World War I and II. This is an example of course of the pursuit of world dominance and the mentality of the German military who believed that they are entitled to the entire continent of Europe and beyond as their required vital space to occupy, conquer and economically exploit with their very well-known ideology "Germany must be above all".

In addition, further examples of this phenomenon include the world domination effort of the Soviet Communist Party during the historic time period of the Soviet Union. In the present time period, the Chinese Communist Party, since undergoing a completely transparent face of communism, the characteristics of economic pan-empire and world wealth domination are already clearly distinguished and again its trends are evident. These efforts of the Chinese Communist Party at the present time are not different than previous efforts to build an economic pan-empire for economic world dominance. Because the Chinese Communist Party, as it turns out, appears as proponents and flag bearers of communist ideology-if ideology is also this new communism, which in reality is just capitalism under a communist veil--is also seeking to capture the world's manufacturing wealth and to use the global manufacturing wealth as means to build the economic pan-empire for world wealth domination.

At the present time, of course, with the significant obvious difference from earlier political systems, is that the Chinese political system has been imposed on their people enforces its current powers - which are the most vigilant and ruthless oligarchy that no human has ever known since compared to the methods of domination of the previous unfree political systems reported earlier in the historical review--this political system seeks to transform humans into helpless beasts or herds of exhausted animals programmed to work like automatons and robots.

The true democracy of ancient Athens is the spiritual leader of humanity. The enormous influence of the ancient Greek philosophers on the true democracy of ancient Athens is reflected in the development and progress of humanity and the creation of civilization.

17. Horatius Flaccus (Horace), Book II Epistle I:156-181. Horace, Satires, Epistles and Ars Poetica (London; Cambridge, Massachusetts: William Heinemann Ltd.; Harvard University Press, 1929). 
The perceptions of the greatest foreign philosophers, scientists, politicians and poets are in agreement about the "Miracle" of the Greek intellect and the invaluable vitality of the immortal Greek spirit and philosophy.

In the following parts of this paper I look and make some remarks on the five criteria of democracy using mainly ancient Greek sources.

\section{Isegoria}

Isegoria is the right of all people to speak equally, as equals for equal time, in the agora where all significant decisions are made during a public debate for very important matters of social and public concern in order to protect and enrich all people's financial interests. Each individual speaker addresses the assembly of all citizens who will vote on the issue under debate. Hence the political right to speak in the agora is also the right of everyone else to listen in order to make a decision on how to vote on the matter at hand.

However, Demosthenes in his speech, "In Favor of Ktesifontos on the Crown" (18.170), refers to the way the parliament of rectors functioned.

"[170] And after that, when the parliament entered, and the rectors announced what had been announced to them, and presented the messenger, and he repeated, although the herald asked 'who wants to speak;', no one appeared to speak. And while the herald many times asked, not even then did anyone rise, though all the generals were present, and all the orators, and the voice of the homeland cries out to him who will speak for its salvation; for the voice which the herald leaves behind by the dictates of the laws, this, it's right, to listen to as a common voice of the homeland."

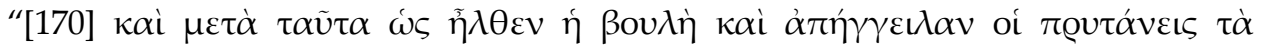

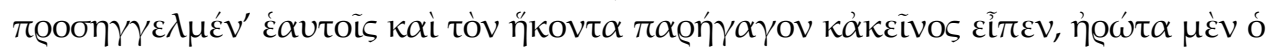

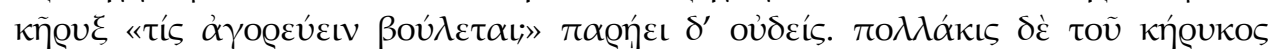

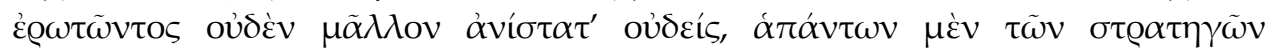

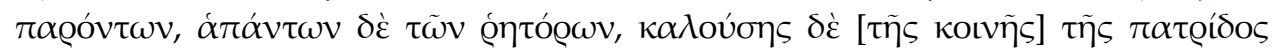

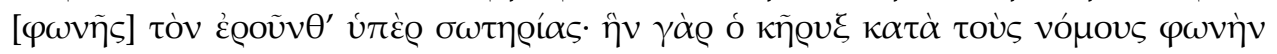

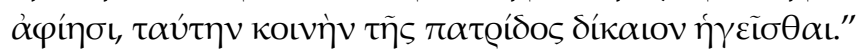

Finley ${ }^{18}$ reports that it is evident beyond any doubt that even in ancient Athens not all possessed the virtue of political wisdom to the same degree. Evidence confirms that few exercised their right to isegoria and that the political leadership remained the monopoly of a relatively oligarchic faction, which, unlike in Rome, did not reproduce itself. The limit of universal political virtue was the universal right to participate in the final decision on equal terms, based on the

18. Finley, Politics in the Ancient World, 1983. 
principle that a man equals one vote. Beyond this limit, the principle of inequality and hierarchy prevailed.

\section{Isonomy}

Isonomy is the right of all people to have equal political and legal rights and to be treated as equals in the eyes of the law. This political system of the true democracy of ancient Athens is evident through the criterion of isonomy, which is quite clearly a direct democracy where -not the oligarchy- all the citizens have equal political and legal rights, participate in the decision-making process and vote for all very important matters of social and public concern in order to protect and increase all people's wealth and financial interests. Isonomy is a critical part of true democracy which excludes the complete opposite of oligarchy, monarchy, tyranny. For example, Plato writes in Republic: ${ }^{19}$

"For example," I said, "a father gets into the habit of becoming like a child and is afraid of his sons, a son becomes like his father and neither respects nor fears his parents, just in order to be free. Resident aliens are equal to citizens and citizens to resident aliens, and foreigners likewise."

"Yes, that's what is happening," he said.

"This and other trivial things like it are happening," I said. "A teacher in such circumstances is afraid of and panders to his pupils; the pupils show contempt for their teachers and likewise for their minders.55 And in general the young ape their elders and compete with them verbally and in their behavior, while old men humor the young with banter and are full of wisecracks and imitate the young so as not to appear disagreeable and authoritarian."

"Absolutely," he said.

"Further, the ultimate in freedom for the masses in my view, my friend, is what happens in such a city when men and women bought as slaves are no less free than those who bought them. We almost forgot to mention how great equality before the law and freedom there is for women in relation to men and men to women."

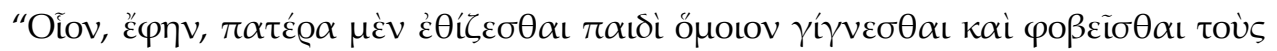

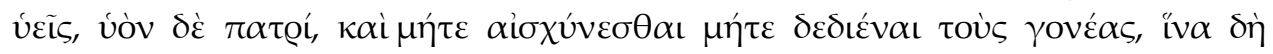

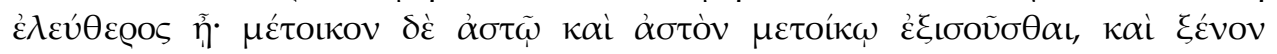
$\omega \dot{\sigma} \sigma \alpha \dot{\tau} \omega \varsigma$.

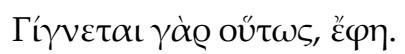

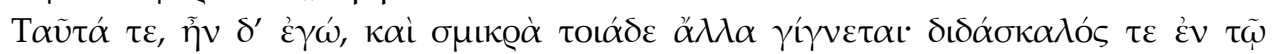

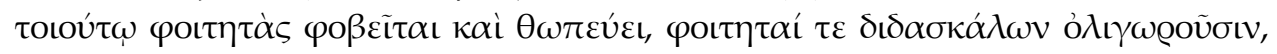

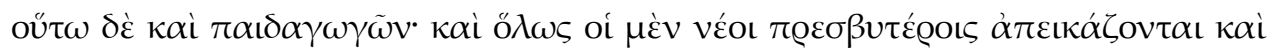

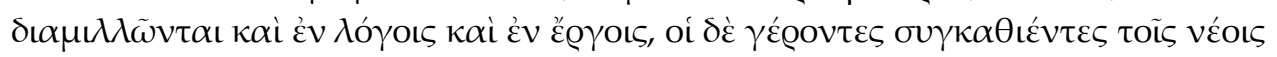

19. Plato, Republic (Harvard University Press, 2013). 


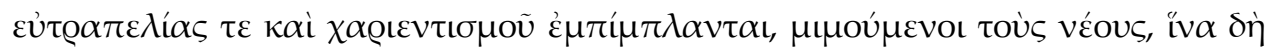

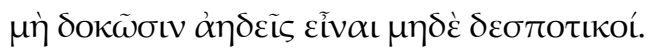

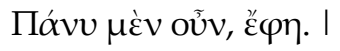

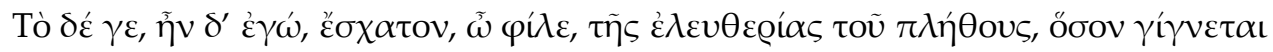

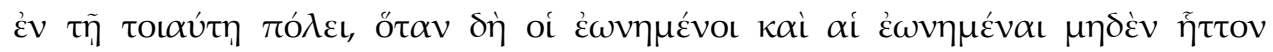

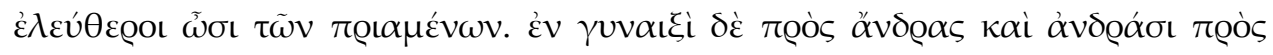

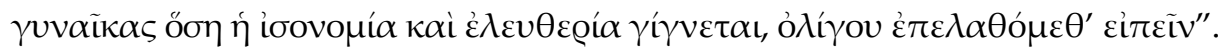

\section{Isocracy}

Modern democracies are representative. Power in them is exercised by the elected representatives of the citizens. On the contrary, the Athenian democracy of classical times was a direct democracy. The true democracy of ancient Athens' main features were citizen sovereignty and political equality, isocracy. Aristotle provides information about the lottery process in his work Constitution, Politeia of

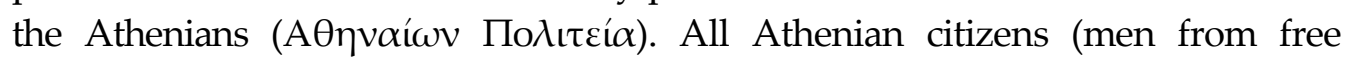
Athenian parents, and who had completed the military training of teenagers) were entitled and obliged to participate with equal rights in the assembly of the municipality (the municipality in the inscriptions), the assembly of Athenian citizens. At the assembly meetings they decided by voting on all public affairs. Their decisions, the resolutions, had the force of law. Herodotus writes in his book History: ${ }^{20}$

"92. Thus spoke the Lacedaemonians, but their words were ill received by the greater part of their allies. The rest then keeping silence, Socles, a Corinthian, said: "Verily the heaven shall be beneath the earth and the earth aloft above the heaven, and men shall dwell in the sea and fishes where men did dwell before, now that you, Lacedaemonians! are destroying the rule of equals and making ready to bring back despotism into the cities-despotism, a thing as unrighteous and bloodthirsty as aught on this earth. For if indeed this seems to you to be a good thing, that the cities be ruled by despots, do you yourselves first set up a despot among yourselves and then seek to set up such for the rest; but now, having never made trial of despots, and taking most careful heed that none shall arise at Sparta, you deal wrongfully with your allies. But had you such experience of that thing as we have, you would be sager advisers concerning it than you are now."

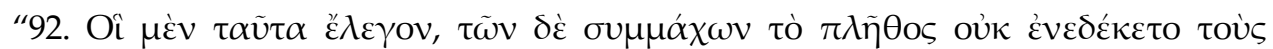

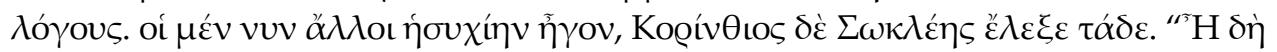

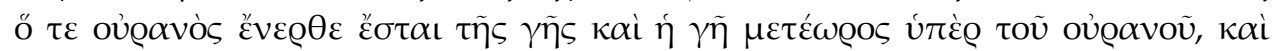

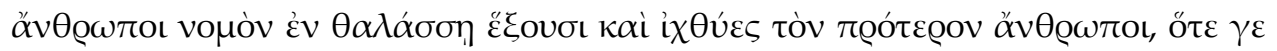

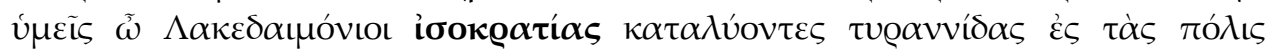

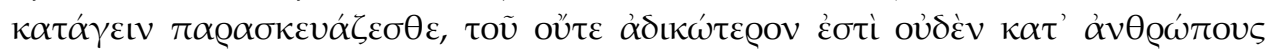

20. Herodotus, The Persian Wars (Harvard University Press, 1920). 


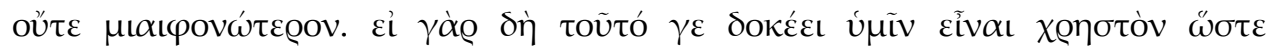

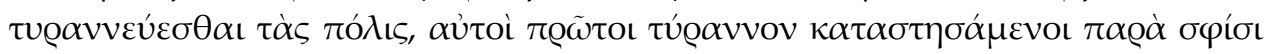

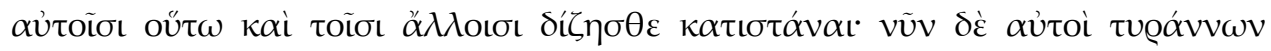

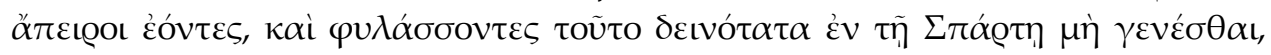

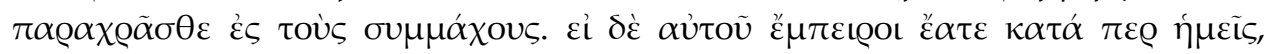

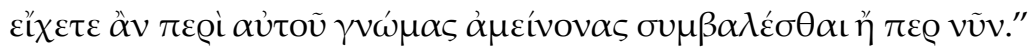

\section{Isoteleia}

Isoteleia in ancient Athens is based equality on duties, civic duties, taxes, liturgies and tributes, according to individual citizens' wealth and properties. Isoteleia is a privilege that the politeia would bestow on foreigners e.g., metics to alleviate them from the additional taxation they were required to pay compared to the full citizens. Isoteleia is an honor and reward to raise metics from their normal status, but without granting them full citizenship. Xenophon writes in his book Hellenica: ${ }^{21}$

"The Thirty thereupon retired to Eleusis; and the Ten, with the aid of the cavalry commanders, took care of the men in the city, who were in a state of great disquiet and distrust of one another. In fact, even the cavalry did guard duty by night, being quartered in the Odeum and keeping with them both their horses and their shields ${ }^{1}$; and such was the suspicion that prevailed, that they patrolled along the walls ${ }^{2}$ from evening onwards with their shields, and toward dawn with their horses, fearing continually that they might be attacked by parties of men from Piraeus. The latter, who were now numerous and included all sorts of people, were engaged in making shields, some of wood, others of wicker-work, and in painting them. And having given pledges that whoever fought with them should be accorded equality in taxation ${ }^{3}$ with citizens even if they were foreigners, they marched forth before ten days had passed, a large body of hoplites with numerous light troops; they also got together about seventy horsemen; and they made forays and collected wood and produce, and then came back to spend the night in Piraeus. As for the men in the city, none of them went forth from the walls under arms except the cavalry, who sometimes captured foraging parties made up of the men from Piraeus and inflicted losses upon their main body."

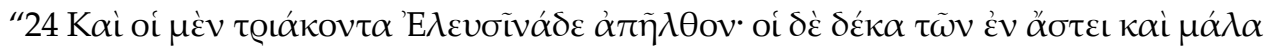

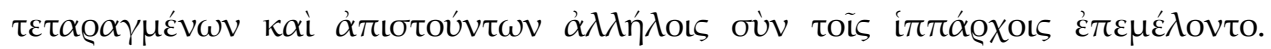

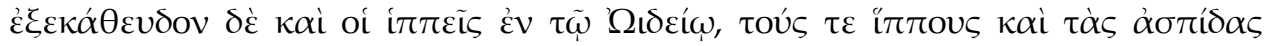

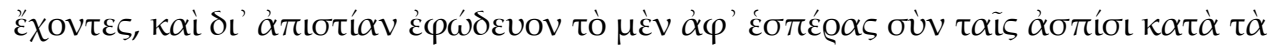

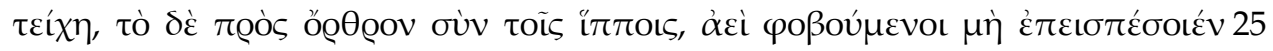

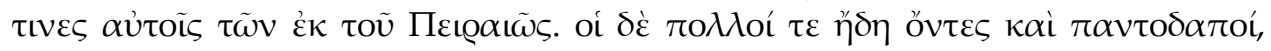

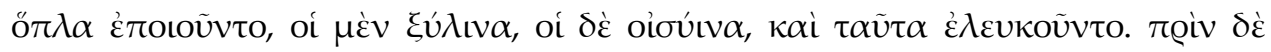

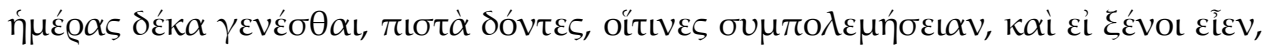

21. Xenophon, Hellenica (Harvard University Press, 1918). 


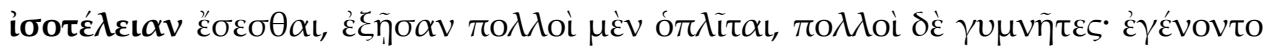

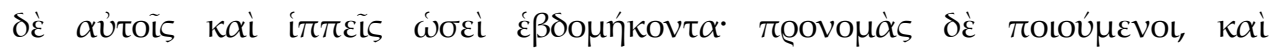

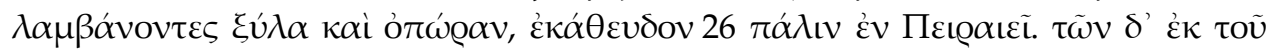

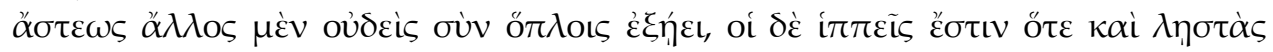

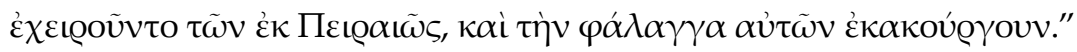

\section{Isopoliteia}

Isopoliteia in ancient Athens is the equality of citizens before the law. The author concurs with Papanikos ${ }^{22}$ who provides a more complete definition of isopoliteia which encompasses and also includes the meaning of equality between city states such as Athens and Sparta. According to the principle of equality, laws have the same consequences for everyone, regardless of the social, economic position of the person they protect or punish. Isopoliteia is also the equality of political rights based on a treaty between two city states. Diogenis Laertios writes in his book Solon Philosophers Bioi: ${ }^{23}$

Solon to Pisistratus

"I am sure that I shall suffer no harm at your hands; for before you became tyrant, I was your friend, and now have no quarrel with you beyond that of every Athenian who disapproves of tyranny. Whether it is better for them to be ruled by one man or to live under a democracy, each of us must decide for himself upon his own judgement. You are, I admit, of all tyrants the best; but I see that it is not well for me to return to Athens. I gave the Athenians equality of civil rights; I refused to become tyrant when I had the opportunity; how then could I escape censure if I were now to return and set my approval on all that you are doing?"

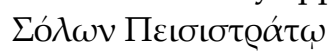

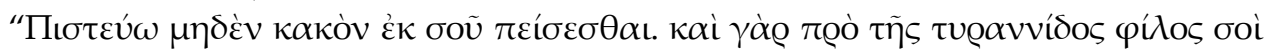

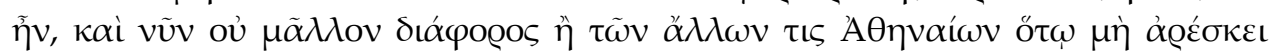

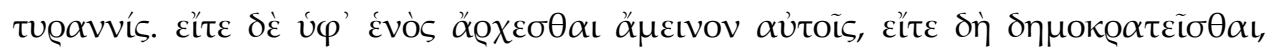

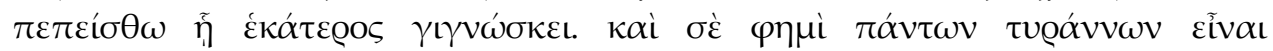

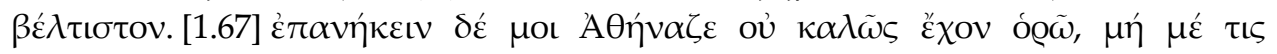

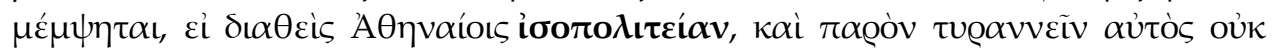

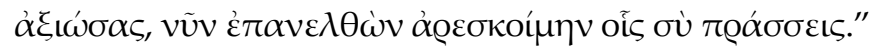

22. Papanikos, "The Five Ancient Criteria of Democracy: The Apotheosis of Equality," 2022.

23. Diogenes Laertius, Lives of Eminent Philosophers. Book I Chapter 2 Solon (Harvard University Press, 1925). 


\section{Conclusions}

My main conclusion is that the five criteria of democracy were well understood by Athenian people as this is demonstrated by the passages of the ancient Greek sources cited in this paper. To a certain extent these criteria shaped the minds of people who actively participated in the democratic process. Of course, these criteria can be quantified using a scale, which can be used to measure how democratic are modern day political systems and how they differ from the political system of ancient Athens.

\section{Bibliography}

Akrigg, B. "The Nature and Implications of Athens' Changed Social Structure and Economy." Debating the Athenian Cultural Revolution: Art, Literature, Philosophy, and Politics (2007): 430-380.

Amit, M. “The Sailors of the Athenian Fleet." Athenaeum 40 (1962): 157-178.

Anderson, G. The Athenian Experiment: Building an Imagined Political Community in Ancient Attica, 508-490 BC. University of Michigan Press, 2003.

Austin, M. M. "Economy and Society." In The Cambridge Ancient History: Volume IV: The Fourth Century, edited by D. M. Lewis, J. Boardman, S. Hornblower, and M. Ostwald, second edition, 527-564, Cambridge, 1994.

Badian, E. "The Road to Prominence." In Demosthenes: Statesman and Orator, edited by I. Worthington, 9-44. London and New York, 2000.

Balot, R. "Courage in the Democratic Polis." The Classical Quarterly 54, no. 2 (2004): 406423.

. "The Dark Side of Democratic Courage." Social Research: An International Quarterly 71, no. 1 (2004): 73-106.

. Greek Political Thought. John Wiley \& Sons, 2008.

. Greed and Injustice in Classical Athens. Princeton University Press, 2020.

Barjamovic, G. Civic Institutions and Self-Government in Southern Mesopotamia in the MidFirst Millennium BC. na, 2004.

Barringer, J. M. The Hunt in Ancient Greece. JHU Press, 2001.

Bassi, K. "The Semantics of Manliness in Ancient Greece." In Andreia, 25-58. Brill, 2003.

Best, J. G. Thracian Peltasts and their Influence on Greek Warfare, volume 1. WoltersNoordhoff, 1969.

Blackman, D. “Archaeology in Greece 1996-97.” Archaeological Reports 43 (1996): 1-125.

Boedeker, D. D., and K. A. Raaflaub. Democracy, Empire, and the Arts in Fifth-Century Athens. Cambridge, Mass: Harvard University Press, 1998.

Boegehold A. L. and A. C. Scafuro (Eds.) Athenian Identity and Civic Ideology. Baltimore, 1994.

Bradeen, D. W. "The Athenian Casualty List of 464 BC." Hesperia: The Journal of the American School of Classical Studies at Athens 36, no. 3 (1967): 321-328.

Bremer, J. M. “Aristophanes on his Own Poetry." In Aristophane, edited by J. M. Bremer and E. W. Handley, 125-165. Geneva, 1993.

Brock, R. “The Emergence of Democratic Ideology.” Historia 40 (1991): 160-169. 
Brock, R., and S. Hodkinson. "Introduction: Alternatives to the Democratic Polis." In Alternatives to Athens: Varieties of Political Organization in Ancient Greece, edited by R. Brock, and S. Hodkinson, 1-43. Oxford, 2000.

Brun, P. Eisphora - Syntaxis - Stratiotika: Recherches sur les Finances Militaires d'Athènes au IVe Siècle av. J.-C. (Eisphora - Syntaxis - Stratiotika: Research on the Military Finances of Athens in the 4th Century BC. J.-C.) Besançon and Paris, 1983.

Bryant, J. M. "Military Technology and Socio-Cultural Change in the Ancient Greek City." Sociological Review 38 (1990): 484-516.

Bugh, G. R. The Horsemen of Athens. Princeton, 1988.

Burian, P. "Myth into Muthos: The Shaping of Tragic Plot." In The Cambridge Companion to Greek Tragedy, 206. 1997.

Campbell, B. "Paradigms Lost Classical Athenian Politics in Modern Myth." History of Political Thought 10, no. 2 (1989): 189-213.

Cargill, J. L. The Second Athenian League: Empire or Free Alliance? Berkeley \& Los Angeles, 1981.

Carothers, T. “The Backlash Against Democracy Promotion." Foreign Affairs (2006): 55-68.

Carson, L., P. F. L. Carson, and B. Martin. Random Selection in Politics. Greenwood Publishing Group, 1999.

Cartledge, P. "The Machismo of the Athenian Empire-Or the Reign of the Phaulus?" When Men Were Men: Masculinity, Power and Identity in Classical Antiquity (1998): 54-67. . Spartan Reflections. Berkeley, 2001.

. The Effects of the Peloponnesian (Athenian) War on Athenian and Spartan Societies. McCann, 2001.

Cawkwell, G. L. “The Defence of Olynthus.” The Classical Quarterly 12, no. 1 (1962): 122140.

. "Demosthenes and the Stratiotic Fund." Mnemosyne 15 (Fasc. 4) (1962): 377-383.

. "Eubulus." The Journal of Hellenic Studies 83 (1963): 47-67.

" "Athenian Naval Power in the Fourth Century." The Classical Quarterly 34, no. 2 (1984): 334-345.

. “Orthodoxy and Hopiltes." The Classical Quarterly 39, no. 2(1989): 375-389.

Diogenes Laertius. Lives of Eminent Philosophers. Book I Chapter 2 Solon. Harvard University Press, 1925.

Finley, M. I. Politics in the Ancient World. Cambridge University Press, 1983.

Fisher, N. R. E. Recherches sur la Nature du Génos: Étude d'histoire Sociale Athénienne-Périodes Archaïque et Classique. (Investigations into the Nature of the Genos: A Study of Athenian Social History-Archaic and Classical Periods.) 1979.

Herodotus. The Persian Wars. Harvard University Press, 1920.

Horatius Flaccus (Horace). Book II Epistle I:156-181. Horace, Satires, Epistles and Ars Poetica. H. Rushton Fairclough. London; Cambridge, Massachusetts: William Heinemann Ltd.; Harvard University Press, 1929.

Moignard, E. C. Berard et al. A City of Images: Iconography and Society in Ancient Greece. Princeton University Press, 2009.

Montesquieu, C. D. “Considérations sur les Causes de la Grandeur des Romains et de leur Décadence (1734)." (Considerations on the Causes of the Greatness of the Romans and Their Decline (1734)). Montesquieu. Oeuvres Complètes. Paris: Gallimard (1949): 69209. 
Nicolet, C. Space, Geography, and Politics in the Early Roman Empire. University of Michigan Press, 1991.

Papanikos, G. T. The Use of European History: Lessons for the 21st Century History. Mimeo, 2005.

. "The Use of History as a Tool of Policy-Making." Opening Speech at the 4th International Conference on History: From Ancient to Modern. Athens, 28-31 December 2006 (Athens: National Archaeological Museum of Athens, 2006).

. "Taxing Wealth and Only Wealth in an Advanced Economy with an Oversized Informal Economy and Vast Tax Evasion: The Case of Greece." Vierteljahrshefte zur Wirtschaftsforschung 84, no. 3 (2015): 85-106.

. "Military Spending, International Trade and Economic Growth in the Mediterranean Basin." Athens Journal of Mediterranean Studies 1, no. 2 (2015): 187-194.

. "Energy Security, the European Energy Union and the Mediterranean Countries." Athens Journal of Mediterranean Studies 3, no. 4 (2017): 341-354.

. "Collective Decision-Making in Homer's Odyssey." Athens Journal of Mediterranean Studies 7, no. 1 (2021): 59-84.

. "The Five Ancient Criteria of Democracy: The Apotheosis of Equality." Athens Journal of Humanities \& Arts 9, no. 2 (2022): 105-120.

. "The Bright Future of Democracy is in Education." Athens Journal of Education 9, no. 2 (2022): 353-364.

Plato. Republic. Harvard University Press, 2013.

Raaflaub K. A., J. Ober, and R. W. Wallace. Origins of Democracy in Ancient Greece. With Chapters by P. Cartledge, and C. Farrar. Berkeley: University of California Press, 2007.

Vergil. "Aeneid." In Book VI, 846-853. Translated by Theodore C. Williams. Boston: Houghton Mifflin Co., 1910.

Vidal-Naquet, P. Economic and Social History of Ancient Greece: An Introduction. Berkeley: University of California Press, 1977.

Xenophon. Hellenica. Harvard University Press, 1918. 
